\author{
Viktor Ventsel ${ }^{1}$
}

\title{
THE EFFICIENCY OF SOCIAL POLICY IN UKRAINE: CHALLENGES AND PROSPECTS
}

Keywords: social policy, remuneration, minimum wage, subsistence level, social protection.

\begin{abstract}
The article considers pertinent issues related to social policymaking and its implementation in Ukraine.

Emphasis is placed on remuneration as the key element of ensuring citizens' welfare and economic development of the state. Remuneration plays one of the most important roles in the economic system and ensuring a decent standard of living. The wage reflects the employee's welfare level and should be correlated with the qualification level and productivity in the production spheres or determined according to the set qualification criteria, quality assessment system and efficiency of employees in non-production spheres. Low remuneration standards and low correlation between wages and productivity affect the motivation of the workforce and reduce its economic and labour activity.

The analysis of the minimum wage and subsistence level as the categories defining the status and directions of economic and social policy of the state has been performed. The minimum wage has a decisive influence on many social and economic processes. A significant issue in Ukraine is that establishing the minimum wage in the legislation is made without objective analysis and taking into account the financial and economic conditions that should be the basis for the state social policymaking. The minimum wage directly affects the volume and structure of the expenditure part of state and local budgets, as it is one of the basic elements for making the payroll of budgetary institutions and organizations. For business structures, the minimum wage is an indicator that reflects the economic and social policy of the state, as well as a microeconomic category that affects their current business activities and the production and financial strategy making.
\end{abstract}

$1 \mathrm{PhD}$ of Economic Sciences, Doctoral Student at the Department of Social and Humanitarian Policy, National Academy of Public Administration under the President of Ukraine, ventsel@ukr.net, ORCID ID: 0000-0002-1902-6126 
Some aspects of the current social protection system in Ukraine have been described. One of the main issues in Ukraine is the excessive number of legislative acts regulating social protection matters. Another important issue is that a significant number of benefits and social transfers, which are stipulated in the legislation and guaranteed to the citizens, cannot be implemented due to lack of financial resources in the state budget. Today, one of the priority tasks of the state policy is to address issues of reforming the social protection system and the introduction of new efficient mechanisms for financing and managing the social services system.

It has been noted about the need to develop and set in the legislation a system of social standards and norms, as well as the development of a standardised mechanism for determining the minimum wage and subsistence level based on and depending on the socio-economic development indicators.

\section{INTRODUCTION}

The state, as an institutional and socio-political entity, at different stages of its evolutionary development ensures the implementation of relevant tasks that are essential for its existence. The main lines of the state's activity are implemented through its functions as the main lines of the state's activity on solving the tasks set by the society, which reveal and detail its essence and social purpose (Aristova, 2006). As a result of civilizational state-building processes, one of the dominant modern concepts was formed - a democratic, social, rule-of-law state, with the social function in the forefront. The generalized understanding of the social function of the state can be defined as one of the state's lines of activities, which is to create the necessary conditions for a decent life regardless of a person's social status and participation in the formation of national income (Aristova, 2006). The social function is characterized by a wide range of areas, including the duty of the state to: ensure a specific level of material welfare of citizens; guarantee the access to education, medical care, promote cultural and physical development; develop infrastructure for the normal life of the members of society, etc. Given this fact, the main goal of devel- 
oping the social sphere of the country shall be increasing the quality of life, which includes not only the consumption of material goods and services but also spiritual needs, health, life expectancy, moral and psychological climate (Pihul et. al., 2015).

The Constitution of Ukraine declares that Ukraine is a democratic, social, rule-of-law state where a person, its life and health, honour and dignity, inviolability and security are recognized as the highest social value (The Constitution of Ukraine). This norm represents the basic principle of the state, which determines the direction of social and economic development. In modern conditions, the most important task for Ukraine is to ensure a sufficient standard of living, reduce financial and material disparities between different social and professional groups, improve the quality of the full range of socially oriented services provided to citizens. However, it shall be noted that the main issue of Ukraine since the declaration of independence is the low standard of living of the vast majority of the population combined with excessive property stratification.

\section{FUNCTIONS AND PURPOSE WAGES}

Remuneration has an important place in the economic system and ensuring a decent standard of living. Low remuneration standards and low correlation between wages and productivity affect the motivation of the workforce and reduce its economic and labour activity. The wage reflects the employee's welfare level and should be correlated with the qualification level and productivity in the production spheres or determined according to the set qualification criteria, quality assessment system and efficiency of employees in non-production spheres.

As an economic category, wages reflect the relationship between employee and employer in the distribution of the value, which is the result of labour (Inshyn et. al., 2016). For a market economy, wages are the price of labour, which is the result of an agreement between an employee who has certain qualifications and skills (owner/seller of labour) and the employer (the buyer of labour). As a social category, wages are a kind of guarantee of ensuring a sufficient standard of living for the person itself 
and its family (Inshyn et. al., 2016), taking into account economic and social development level of the state.

The function of wages is to ensure the material and intangible needs of the employees while taking into account the interests of the employer (Malytska, 2011). The function of wages is its purpose in the system of relations and politics of the subjects of social and labour relations, i.e. the employee and the employers. The main functions of wages are reproductive, stimulating, regulatory, social (Malytska, 2011; Luniak, 2015). The purpose of the reproductive function is to provide the employee and his family with the necessary resources and life benefits to restore physical potential and meet spiritual needs (Luniak, 2015). The stimulating function involves the dependence of the wages level on the quantity (volume), quality and results of work. The regulatory function is a means of distribution and redistribution of the workforce by type of economic activity, a region of the country, qualification level, specialization, workforce quality (Luniak, 2015). Social justice and non-discrimination in remuneration shall be ensured through the social function. The social function can be best ensured through the use of state regulation and contractual relations. Ukrainian legislation, namely the Law of Ukraine "On Remuneration", stipulates the state focus on ensuring only the reproductive and stimulating functions of the wages (Law on salaries).

Given the functioning of market mechanisms for regulating the economy, the employees do not always have the opportunity to receive fair remuneration for their work, due to private interests of employers to maximize their income and a competitive business environment. In this case, partial state regulation of the relationship between employees and employers is necessary. One of the main levers of state influence on the remuneration level in the production and non-production sectors is establishing social guarantees for remuneration (minimum wage, subsistence level). The minimum wage is the main component in the system of state social guarantees. Its amount depends on the economic capacities of the state and the established system for calculating it. However, there are general indicators that enable assessing the living standards of the population. For instance, World Bank experts believe that living on less than $\$ 1.9$ a day means extreme poverty (Cruz et. al., 2015). This figure applies 
to the poorest countries. Living on less than $\$ 3.2$ a day is the poverty line for lower-middle-income countries, and $\$ 5.5$ a day sets the poverty line for upper-middle incomes (Cruz et. al., 2015). In addition to the financial aspect, the poverty issue also has a non-monetary dimension, which is manifested in limited access of citizens to tangible and intangible goods and services that are necessary for a common way of life in the relevant society. According to international criteria, poverty indicators include, among other things, the inability to have a telephone, TV and other household appliances, as well as the inability to spend a one-week vacation away from home once a year. Besides, poverty does not allow citizens to properly exercise their rights to education, health care and other social and humanitarian services. For example, parents' lack of funds for the education of their children reduces the opportunities of the latter to obtain relevant qualifications and ensure an adequate level of their welfare in the future. A significant proportion of the poor reduces demand, purchasing power and, as a consequence, negatively affects producers of goods and services. The political context also has a negative impact on poverty. The difficult financial situation of citizens is used by politicians to bribe the electorate, as well as to manipulate with primitive populist election slogans to quickly improve the financial situation of citizens. Therefore, the issue of poverty goes far beyond the lack of money. Lack of effective economic and social strategy, institutional incapacity of state authorities, inefficient use of available financial and material resources of the state, corruption these and many other factors directly affect the ability to overcome (or not) poverty and improve living standards.

\section{MINIMUM WAGE AND SUBSISTENCE LEVEL IN THE SOCIAL STANDARDS SYSTEM OF UKRAINE}

The minimum wage has a decisive influence on many social and economic processes. A significant issue in Ukraine is that establishing the minimum wage in the legislation is made without objective analysis and taking into account the financial and economic conditions that should be the basis for the state social policymaking (Ventsel, 2019). 
The minimum wage directly affects the volume and structure of the expenditure part of state and local budgets, as it is one of the basic elements for making the payroll of budgetary institutions and organizations. For business structures, the minimum wage is an indicator that reflects the economic and social policy of the state, as well as a microeconomic category that affects their current business activities and the production and financial strategy making.

The issue of raising the level of wages and their purchasing power shall be addressed in terms of creating conditions for accelerating the economic development pace of Ukraine. Only in the context of developing industries and spheres that generate added value and promote legal employment is it possible to increase not only the minimum wage but also the general level of real incomes and improve the quality of life. At the same time, it is necessary to regulate wages through the budgetary policy mechanisms by establishing their optimal size, which would meet the capacities of the economy and ensure real growth of income (Ventsel, 2019).

As of today, wages in Ukraine do not ensure the proper performance of its functions due to the low level of economic development, lack of effective state regulation and supervision, poor control in the field of preventing abuse regarding payment of wages.

The system of state regulation of labour relations needs to be radically and urgently improved to ensure compliance with the rights of employees to adequate remuneration for their labour participation and minimize opportunities for abuse of remuneration by employers. The legislative field governing the payment of the minimum wage and subsistence level needs to be improved too. The minimum wage shall have a function of the minimum level of monetary remuneration for labour that does not require qualifications or be a guaranteed baseline amount for the payment of wages. These days, the remuneration system in Ukraine allows to accrue wages below the minimum, however, in the future the employer must make a mandatory additional accrual to the minimum wage level. This is a demotivating aspect in terms of the stimulating and regulatory functions of wages. The regulatory influence of the state shall be manifested in the economically justified establishment of the nominal size of the subsistence minimum, which should be as close as possible to its actual value accord- 
ing to the established standards and physiological human needs. In this regard, it is necessary to develop a systematic mechanism for determining the minimum wage and subsistence level depending on the indicators of socio-economic development, taking into account the objective human vital needs.

Social policy in Ukraine is largely based on the use of the subsistence level as a basic standard for determining state social guarantees, as well as standards in the fields of income, housing, communal, household, socio-cultural services, education and health care (Nebava, 2012). The Law of Ukraine "On the Subsistence Minimum" stipulates that the subsistence minimum is a monetary value sufficient to ensure a set of food for normal functioning of the human body and maintaining its health, as well as a minimum set of non-food items and a minimum set of services necessary to meet basic social and cultural needs of the individual (Law on living wage). The subsistence level is determined using the normative method per month per person, as well as individually for social and demographic groups: children under the age of 6; children aged 6 to 18; able-bodied persons; disabled persons (Law on living wage). The socio-economic importance of the subsistence level is in the fact that it is used to assess the general standard of living in the country, establish pensions and social benefits for various categories of citizens, the formation of state and local budgets. Article 46 of the Constitution of Ukraine stipulates that pensions, other types of social benefits and aid, which are the main source of subsistence, must provide a standard of living, which is not lower than the subsistence level established by law (The Constitution of Ukraine). At the same time, in addition to the nominal subsistence level established by law, the Ministry of Social Policy of Ukraine calculates the actual subsistence level, which differs significantly from the one set in the legislation (table1).

These data show that the size of the subsistence minimum set by the law is almost half of its actual size, which is calculated based on average prices for consumer goods and services and rates for housing and communal services. In this way, we can state that the subsistence level established by the laws of Ukraine cannot secure the right to a set of food, which is sufficient to ensure the normal functioning of the human body 
Table 1. Comparative analysis of the subsistence minimum in Ukraine for 2015-2020

\begin{tabular}{|c|c|c|c|c|}
\hline Periods & $\begin{array}{c}\text { Average annual } \\
\text { subsistence level } \\
\text { for able-bodied } \\
\text { persons (establi- } \\
\text { shed by law), UAH }\end{array}$ & $\begin{array}{c}\text { Actual average annual } \\
\text { subsistence level for able- } \\
\text {-bodied persons } \\
\text { (excluding personal } \\
\text { income tax), UAH }\end{array}$ & \multicolumn{2}{|c|}{ Departure } \\
\cline { 4 - 5 } A & $\mathbf{1}$ & $\mathbf{2}$ & total, UAH & percentage \\
\hline 2015 & 1271,3 & 2361,0 & $-1089,7$ & $\mathbf{4}=\mathbf{1} / \mathbf{2}$ \\
\hline 2016 & 1438,5 & 2708,0 & $-1269,5$ & $53,8 \%$ \\
\hline 2017 & 1662,5 & 3040,0 & $-1377,5$ & $54,7 \%$ \\
\hline 2018 & 1808,2 & 3376,0 & $-1567,8$ & $53,6 \%$ \\
\hline 2019 & 1971,9 & 3791,0 & $-1819,1$ & $52,0 \%$ \\
\hline 2020 & 2155,6 & $3983,0 *$ & $-1827,4$ & $54,1 \%$ \\
\hline
\end{tabular}

* as of April 2020

Source: own compilation based on data of the Laws on the State Budget for 2015-2020, The actual cost of a living wage in 2015-2020.

and maintaining its health, as well as a minimum set of non-food items and a minimum set of services necessary to meet basic social and cultural needs of the individual, guaranteed in the Law of Ukraine "On subsistence minimum" (Law on living wage).

\section{SOCIAL PROTECTION OF THE POPULATION AND WAYS OF ITS REFORM}

One of the important tasks that require solution is the reform of the social protection system. The current legislation norms of Ukraine stipulate that the system of social protection includes: social security in case of unemployment (loss of job) and in case of temporary disability; financial assistance to different categories of citizens, depending on the living conditions that necessitated such assistance (benefits, subsidies, various types of assistance); social services for the elderly and other categories of citizens. 
The reform of the social protection system, as well as the change of approaches to the social policy-making of the state, is a long-overdue issue that no Government of modern independent Ukraine has dared to solve definitively. Social policy shall aim at the social protection of various social and gender groups, with special emphasis on those who are in difficult life circumstances. Accordingly, an effective social protection policy shall include not only the provision of social payments (benefits) by the state but also the formation and operation of a network of social services provided to different categories of citizens with the most personalized consideration of their needs. The main purpose of this system of organization and provision of social services is the focus on meeting the citizens' needs and improving their quality of life. Today, under the conditions of aggravating economic problems, the number of citizens in need of social protection in Ukraine is increasing.

One of the main problems of Ukrainian social protection system is the excessive number of legislative acts. It is estimated that the provision of various types of benefits on social and professional grounds, as well as the social payments and the provision of social services are regulated by 58 laws and more than 120 bylaws (Report-monitoring of the social services system in Ukraine, 2015).

Another important issue is that a significant number of benefits and social payments, which are stipulated in the legislation and guaranteed to the citizens, can not be implemented due to lack of financial resources in the state budget. Nevertheless, the process of expanding the welfare beneficiaries and types of social benefits does not stop. From time to time, new legislation is adopted, which provides for the introduction of new social benefits. Here attention shall be paid to another problem - the issue of forming political responsibility for decision-making, which determines specific social guarantees for citizens, which cannot be provided due to lack of budget funding. According to the estimates (Report-monitoring of the social services system in Ukraine, 2015), the total value of benefit payments declared in Ukrainian legislation ranges from USD 3.8 to 5.8 bln per year. It is worth noting that there are more than 130 categories of recipients of various social benefits in Ukraine, of which 70 categories - on social grounds and about 50 categories - on professional grounds (Report- 
monitoring of the social services system in Ukraine, 2015). Welfare beneficiaries are entitled to more than 120 types of benefits and more than 60 types of social and compensation payments (Report-monitoring of the social services system in Ukraine, 2015). It is estimated that the real amount of expenditures for financing the social protection and social security spheres shall be at least 2.5-3 more than actually foreseen in the budget (Report-monitoring of the social services system in Ukraine, 2015).

An important problem that requires significant consideration is that the current social protection system is aimed only at providing a specific level of financial support and barely aimed at assisting citizens in overcoming difficult life circumstances or taking preventive measures for the people not to get into difficult life circumstances.

Special attention shall be paid to the formation of a flexible system of financing various types of benefits, assistances and compensations. It is a question of financing the specified payments based on financial possibilities of the state and local budgets, instead of based on the declared (established) needs. The legislative mechanism shall provide tools for setting norms and standards for the provision of relevant services or financial benefits, depending on the revenue capacity of the budget. In the process of decentralization of management and financial resources, it is necessary to separate the powers and responsibilities between the state and local self-government bodies regarding the provision of social services and the implementation of social payments. At the local level, it makes sense to introduce mechanisms to engage all (or at least a significant part) of community members in identifying ways and opportunities to solve local social problems.

In general, the social protection system is a very complex mechanism that is closely intertwined with the economic system and the economic development strategy of the state. Ukraine shall finally decide on the system of economic relations and based on this make a new social protection system. Currently, Ukraine has a post-Soviet socialist system, which contradicts the market mechanisms that were tried to be implemented since independence. One clear example is the current subsidy system. By definition, subsidies can be provided by the state to support and stimulate 
strategic lines or industries to receive economic or social effects. The most common is subsidizing agriculture to ensure food security of the state and given the risky nature of production due to subjective factors that do not depend on human will. Besides, the system of subsidies can be used for the development of strategic industries to receive future economic benefits like jobs, growth of gross domestic product and budget revenues. The subsidy is intended to stimulate specific actions that the state intends to promote or intensify. Unlike the aforementioned approach, in Ukraine, the system of subsidies is mainly associated with the provision of subsidies to citizens as a compensation for the cost of housing and communal services and the cost of energy resources consumed by households. There is no doubt that the state must provide assistance to citizens that need it. However, the existing approach to subsidies cannot be considered completely justified and the one that meets the principles of a market economy (which we declare). The state directly sets rates for energy resources, as it owns the main enterprises of the energy sector, and also indirectly influences the establishment of other rates, where the fee for energy resources is one of the parts. Experience has proven that the formation of these rates is not always transparent and reasonable. The next step is for the state to provide subsidies to citizens to pay for relevant maintenance services for their own housing. This mechanism definitely has nothing to do with the market economy, where pricing is usually formed based on supply and demand. Consequently, the subsidization of private housing takes place in Ukraine. One of the negative factors of existing subsidy system in Ukraine is that this approach completely paralyzes economic processes (particularly, in terms of housing infrastructure upgrade) and creates conditions for permanent dependence of a large part of the population on state assistance. On the other hand, to some extent, the subsidies hinder wage growth because employees do not have sufficient incentives to demand pay rise from the employer. Besides, the subsidy system encourages the development of shadow wages, as it becomes beneficial for employees to reduce their official income to receive state assistance.

The social protection system is a rather complex category of state economic and social policy and an extremely sensitive political issue given the electoral mood. At the same time, solving the issues of reforming the 
social protection system, introduction of new efficient mechanisms of financing and managing the social services system is one of the priority tasks of the state policy. The state resource base has long been an inadequate social obligation. It shall be clear that the preservation of the existing social services system will lead to extremely negative economic and social consequences in the medium-term period.

\section{CONCLUSIONS}

Ukraine's economic growth rate is too low to reduce poverty and reach incomes of the neighbouring European countries (Realization of Ukraine's economic growth potential. Special report, 2019). Due to its dependence on commodity exports, Ukraine remains vulnerable to foreign economic shocks and price cycles in commodity markets (Economic review. Ukraine, 2019). A severe problem on the way to economic development and improving the welfare of the population is the low efficiency of the workforce, capital and land use. The average worker in Germany produces as many products (works, services) in 17 days as the average worker in Ukraine in one year (Realization of Ukraine's economic growth potential. Special report, 2019). Significant differences in the level of labour productivity compared to developed countries are due to both Ukraine's lag in production efficiency and less fixed assets (Realization of Ukraine's economic growth potential. Special report, 2019). Despite some progress in bridging the labour and capital efficiency gap, Ukraine remains limited in its fixed assets due to a lack of investment, including foreign direct investments (Realization of Ukraine's economic growth potential. Special report, 2019). The level of capital per employee in Ukraine is at the same level as in the late 1990s (Realization of Ukraine's economic growth potential. Special report, 2019). In 2020, these problems were exacerbated by the de facto suspension of the global and Ukrainian economies due to the pandemic of COVID-19 acute respiratory disease caused by the SARS-CoV-2 coronavirus.

Economic and budgetary policies play a system-making and determining role in the processes of ensuring the implementation of the state social 
function. Today, among the current issues that need further research and solutions are the following:

1. the need to develop and set in the legislation the system of social standards and norms, namely: indicators of cost and in-kind consumption of food and household goods, utilities, medical devices, transport services, cultural and educational services and other vital goods, works and services in terms of the regions to take into account the territorial features of socio-economic development as much as possible. This requires making a detailed statistical database on all aspects of life necessities of the citizens, which will be the basis for making relevant calculations. Maximum detail will allow more complete and objective calculation of the necessary indicators, standards and regulations (Ventsel, 2019);

2. development of a standard mechanism for determining the minimum wage and subsistence level based on and depending on the socio-economic development indicators. The coherence of social standards and results of economic activity and social development will help eliminate the subjective influence in their establishment and prevent the development of excessive escalation processes (Ventsel, 2019);

3. formation of strategic directions of a budget policy aimed at stimulating economic activity, eliminating disparities in regional socio-economic development, protection of socially vulnerable groups by providing the necessary types of assistance. The modern system of state funding of various benefits and subsidies has proved its inefficiency, does not contribute to the social protection of those that need it, in many cases acts as a disincentive factor and does not motivate citizens to work (Ventsel, 2019).

\section{BIBLIOGRAPHY:}

Aristova I. V. (2006) Sotsialna funktsiia derzhavy yak vyznachalna katehoriia prava sotsialnoho zabezpechennia Ukrainy [Social function of the state as a determining category in the law of Ukraine social security]. Forum prava, no. 2, pp. 18-21. 
Cruz M., Foster J. et al. (2015) Ending Extreme Poverty and Sharing Prosperity: Progress and Policies. Policy Research Notes. World Bank, October 2015.

The World Bank (2019) Ekonomichnyi ohliad. Ukraina [Economic review. Ukraine]. Downloaded from: http://pubdocs.worldbank.org/en/72416155860 1576209/Ukraine-Economic-Update-Spring-2019-uk.pdf

Faktychnyi rozmir prozhytkovoho minimumu u 2015-2020 rokakh [The actual cost of living wage in 2015-2020]. Official web-site Ministry of Social Policy. Downloaded from: https://www.msp.gov.ua/news/12286.html

Inshyn M.I., Kostiuk V.L. et al. (2016) Trudove pravo Ukrainy: pidruchnyk [Labor law of Ukraine: textbook]. Kyiv: Tsentr uchbovoi literatury [in Ukrainian].

Konstytutsiia Ukrainy [The Constitution of Ukraine]. Downloaded from: http://zakon. rada.gov.ua/laws/show/254\%D0\%BA/96-\%D0\%B2\%D1\%80

Luniak I. V. (2015) Zarobitna plata yak naivazhlyvishyi faktor realizatsii investytsiinoinnovatsiinoi modeli rozvytku [Wages as the most important factor in the implementation of investment and innovation model of development]. Investytsii: praktyka ta dosvid, no. 21, pp. 21-24.

Malytska I. D. (2011) Funktsii zarobitnoi platy ta stan yikh vykonannia v Ukraini [Wage functions and the state of their implementation in Ukraine]. Derzhava i pravo, no.51. pp. 409-413.

Nebava M. I. (2012) Protyrichchia formuvannia prozhytkovoho minimumu v Ukraini yak bazovoho standartu sotsialnoi polityky [Contradictions in the formation of the subsistence level in Ukraine as a basic standard of social polic]. Scientific Bulletin of the Academy of Municipal Administration, no. 11, pp. 152-167.

Pihul N., Liuta O. et al. (2015) Finansove zabezpechennia sotsialnoi sfery v Ukraini [Financial support of social sphere in Ukraine]. Herald of the National Bank of Ukraine, no. 1 (227), pp. 30-35.

Pro Derzhavnyi biudzhet Ukrainy na 2015 rik: Zakon Ukrainy vid 28.12.2014 № 80 [Law on the State Budget for 2015]. Retrieved from: https://zakon.rada.gov.ua/laws/ show/80-19

Pro Derzhavnyi biudzhet Ukrainy na 2016 rik: Zakon Ukrainy vid 25.12.2015 № 928 [Law on the State Budget for 2016]. Downloaded from: https://zakon.rada.gov.ua/ laws/show/928-19

Pro Derzhavnyi biudzhet Ukrainy na 2017 rik: Zakon Ukrainy vid 21.12.2016 № 1801 [Law on the State Budget for 2017]. Downloaded from: https://zakon.rada.gov.ua/ laws/show/1801-19

Pro Derzhavnyi biudzhet Ukrainy na 2018 rik: Zakon Ukrainy vid 07.12.2017 № 2246 [Law on the State Budget for 2018]. Downloaded from: https://zakon.rada.gov.ua/ laws/show/2246-19 
Pro Derzhavnyi biudzhet Ukrainy na 2019 rik: Zakon Ukrainy vid 23.11.2018 № 2629 [Law on the State Budget for 2019]. Downloaded from: https://zakon.rada.gov.ua/ laws/show/2629-viii

Pro Derzhavnyi biudzhet Ukrainy na 2020 rik: Zakon Ukrainy vid 14.11.2019 № 294 [Law on the State Budget for 2020]. Downloaded from: https://zakon.rada.gov.ua/ laws/show/294-IX

Pro oplatu pratsi: Zakon Ukrainy vid 24.03.1995 № 108/95 [Law on salaries]. Downloaded from: https://zakon.rada.gov.ua/laws/show/108/95-\%D0\%B2\%D1\%80

Pro prozhytkovyi minimum: Zakon Ukrainy vid 15.07.1999 № 966 [Law on living wage]. Downloaded from: https://zakon.rada.gov.ua/laws/show/966-14\#top

The World Bank (2019) Realizatsiia potentsialu ekonomichnoho rostu Ukrainy. Spetsialna dopovid [Realization of Ukraine's economic growth potential. Special report]. Downloaded from: http://pubdocs.worldbank.org/en/233891558601579588/ Ukraine-Special-Focus-Note-Spring-2019-uk.pdf

Ventsel V.T. (2019) Sotsialno-ekonomichnyi analiz oplaty pratsi yak atrybutyvnoi oznaky sotsialnoi funktsii derzhavy [Social-economic analysis of wages as an attributive indication of the social function of the state] Public management and administration in Ukraine, no. 9, pp. 17-21.

Bureau of Social and Political Development (2015) Zvit-monitorynh systemy sotsialnykh posluh v Ukraini [Report-monitoring of the social services system in Ukraine]. Downloaded from: https://bureau.in.ua/downloads/social-reform/reportua.pdf 